\section{Tree Irrigation Levels for Optimum Chemical and Sensory Properties of Olive Oil}

\author{
Maria J. Berenguer \\ University of California Land, Air, Water Resources, One Shields Avenue, \\ Davis, CA 95616
}

Paul M. Vossen ${ }^{1}$

University of California Cooperative Extension, 133 Aviation Boulevard, Suite 109, Santa Rosa, CA 95403

\section{Stephen R. Grattan \\ University of California Land, Air, Water Resources, One Shields Avenue, Davis, CA 95616}

\section{Joseph H. Connell \\ University of California Cooperative Extension, 2279 Del Oro Avenue, Suite B, Oroville, CA 95965}

\section{Vito S. Polito \\ University of California Department of Plant Science, One Shields Avenue, Davis, CA 95615}

Additional index words. 'Arbequina', fatty acids, polyphenols, extra virgin, quality, superhigh-density

\begin{abstract}
A comparative study was conducted to evaluate the influence of seven different levels of irrigation applied to 'Arbequina I-18' olive (Olea europaea L.) trees grown in a super-high-density orchard $(1,656$ trees/ha) in the Sacramento Valley of California. Water was applied differentially by drip irrigation at rates of $15 \%, 25 \%, 40 \%, 57 \%, 71 \%$, $89 \%$, and $107 \%$ evapotranspiration (ETc) in 2002, and $28 \%, 33 \%, 55 \%, 74 \%, 93 \%$, $117 \%$, and $140 \%$ ETc in 2003. Each treatment was replicated three times. Olives were harvested on two different dates each year from each of 21 plots. Three of four harvest dates showed a decrease in maturity index with increasing irrigation levels. Oils were made from olive samples collected from each plot and analyzed for oil quality parameters. Total polyphenol levels and oxidative stability decreased as the trees received more water, especially for the three lowest irrigation treatment levels in 2002, but few differences were noted between treatments in $\mathbf{2 0 0 3}$ when all the trees were irrigated more heavily. Average oxidative stability was correlated very closely with total polyphenol content with $r^{2}=$ 0.98 in 2002 and 0.94 in 2003. In 2002, free fatty acid levels increased and peroxide levels were unchanged, but in $\mathbf{2 0 0 3}$, free fatty acid levels were unchanged and peroxide levels decreased in treatments receiving more water. Saturated fatty acids did not significantly change in 2002, due to tree irrigation level. The mono-unsaturated fatty acid levels and oleic-linoleic relationship declined while poly-unsaturated fatty acid levels increased in 2002 with increased irrigation. In 2003, there was no notable difference in the ratio of mono to poly unsaturated fatty acid levels. The individual fatty acid most consistently affected by more irrigation water was stearic, which decreased in both years. Total sterol content $\left(\mathbf{m g} \cdot \mathbf{k g}^{-1}\right)$, percentages of cholesterol and erythrodiol were significantly influenced by tree irrigation levels, but increased in one year and either decreased or were unchanged the next. Oil sensory properties of fruitiness, bitterness, and pungency all declined in oils made from trees receiving more water. The lowest irrigation levels produced oils that were characterized by excessive bitterness, very high pungency, and woody, herbaceous flavors. Intermediate irrigation levels (33\% to $40 \%$ ETc) produced oils with balance, complexity, and characteristic artichoke, grass, green apple, and some ripe fruit flavors. Higher irrigation levels lowered oil extractability and produced relatively bland oils with significantly less fruitiness and almost no bitterness or pungency.
\end{abstract}

Received for publication 22 Sept. 2005. Accepted for publication 2 Dec. 2005. We thank the members of the California Olive Oil Taste Panel: Alexandra Devarenne, Franco Dunn, John Hadley, Rick Jones, Arden Kremer, Nancy Lilly, Deborah Rogers, Mark Roper, Stephen Tylicki, and Dean Wilkinson. We thank Maria Soledad Gracia Gómez at the Laboratorio Agroambiental Diputación General de Aragón, Juan Ramon Izquierdo Laboratorio Arbitral Agroalimentario M.A.P.A., Madrid, and Mike Denny, Alan Greene, and Miguel Lopez at the California Olive Ranch.

${ }^{1}$ Reprint requests should be addressed to pmvossen@ucdavis.edu.
Historically, olives for oil production have been dry farmed (nonirrigated), in Mediterranean climates where almost all precipitation occurs in the winter months. Olive trees were traditionally planted at wide spacings so they would have enough stored soil moisture for the entire growing season. Modern orchards have been planted at higher densities and are irrigated. These orchards achieve heavier yields and alternate bearing is reduced. (Beede and Goldhammer, 1994). Irrigation can dramatically increase fruit yields per hectare and consequently increase total production of oil, even though the percent of oil in an individual fruit declines (d'Andria et al., 2002; Goldhammer et al., 1994; Lavee et al., 1990; Moriana et al., 2003). Some researchers also found that extraction of oil from the fruit in the milling process was affected by tree irrigation level (Girona et al., 2002; Faci et al., 2000). The amount of irrigation water that olive trees receive also affects oil quality characteristics such as acidity; polyphenol content; K-232; K270; K-225 (bitterness); and oxidative stability. In most cases these researchers found that the polyphenol content, and oxidative stability was reduced by increased orchard irrigation levels, but some found enhanced polyphenol levels in irrigated trees when comparing only two treatments, dry-farmed to irrigated (Beltrán et al., 1995; Faci et al., 2002; Gucci et al., 2004; Inglese et al., 1996; Ismail and Stavroulakis, 1999; Salas et al., 1997; Tovar et al., 2002). The effects of different irrigation levels on oil sensory characteristics was found in most cases to reduce fruitiness, bitterness and pungency as trees were given more irrigation water. All of this work was conducted in either old widely spaced orchards or more modern orchards with intermediate tree spacings and most of the evaluations compared only a few different irrigation levels.

The super-high-density system $(1,500$ to 2,500 trees/ha) was developed within the last decade to facilitate the use of over-the-row mechanical harvesters and to bring orchards into production within a few years after planting. To accommodate the harvester, vigor must be managed to limit tree size while maintaining high productivity. The tree spacing, pruning, weed control, pest management, nutrition and irrigation are being managed very intensively within these orchards, but little has been documented about how changes within cultural practices might affect performance. In this experiment we collected data from Arbequina olives grown in a super-high-density system measuring the effects of seven different irrigation levels on shoot growth, flowering, fruit set, fruit size, fruit maturity, oil extraction, oil chemical attributes, and oil sensory characteristics. The goal of this experiment was to determine the effect of different irrigation treatments on fruit maturity, oil extractability, and the sensory and chemical parameters of the olive oil. The orchard was located in the Northern Central Valley of California where the climatic conditions are generally regarded to have higher average temperatures and greater light intensity than most locations in Europe. We wanted to document which irrigation levels provided 
for optimum oil flavor and chemical characteristics that would also coincide with some water conservation and tree vigor management. The horticultural parameters and water usage figures are documented in a separate paper (Berenguer et al., 2004).

\section{Materials and Methods}

Seven different irrigation treatments were applied in the fourth and fifth growing seasons in a super-high-density planting $(1.55 \times 3.9 \mathrm{~m}$, 1,656 trees/ha) of 'Arbequina I-18' olives in 2002 and 2003. The orchard is located in the Sacramento Valley of California near Oroville. The soil is described as a Redding gravel sandy loam with a hard pan at about 1 meter. The climate is interior Mediterranean with many days reaching $38^{\circ} \mathrm{C}$ during the summer. Olive evapotranspiration $(\mathrm{ETc})$ was estimated using the daily reference evapotranspiration (ETo) provided by a nearby California Irrigation Management Information System (CIMIS) weather station and a crop coefficient $(\mathrm{Kc})$ that was determined experimentally (Beede and Goldhamer, 1994) and adjusted at our experimental site using a reduction coefficient (Kr) (Fereres and Castel, 1981) to account for orchard canopy coverage. Therefore the water use of the olive trees (ETc) was calculated as $\mathrm{ETc}=\mathrm{ETo} \times \mathrm{Kc} \times \mathrm{Kr}$. Canopy coverage was measured at the beginning of the experiment and again after fruit harvest. The experiment was designed as a randomized block with three replications. Each of the 21 plots consisted of three, eight-tree rows. The center four trees were used for all measurements and harvest; surrounding guard trees eliminated the influence of one treatment on the next. The trees were drip irrigated with different combinations of 2 and $4 \mathrm{~L} \cdot \mathrm{h}^{-1}$ pressure-compensating emitters (one to three emitters/tree) in order to achieve the various application rates. Average irrigation frequency was five to six times per month over the season.

In 2002, the season-long irrigation treatments started on 24 Apr. and lasted until 9 Oct. Each of the treatment trees received 32 irrigations during the season as a percentage of evapotranspiration (ETc) 15\% (341 L), 25\% (591 L), 40\% (1,182 L), 57\% (1,773 L), 71\% $(2,364 \mathrm{~L}), 89 \%(2,955 \mathrm{~L})$ and $107 \%(3,546 \mathrm{~L})$. The lowest water-application treatment differed from the other treatments in that initially the trees were without irrigation (until 22 July when they showed considerable stress). At this time a single emitter per tree was added, which applied the same rate as the second-lowest $(25 \%$ Etc) water application treatment. Fruit was harvested on two different dates, 31 October and 18 November.

In 2003, the grower cooperator wanted to increase total growth in the young trees, which had been observed in the trees receiving more water the previous year. The frequencies of all the irrigation treatments were increased to 12 to 14 times per month. Each of the treatment trees received the following percentages of ETc and corresponding liters of water for the season in 68 irrigations: $28 \%(653 \mathrm{~L}), 33 \%(796 \mathrm{~L})$, $55 \%(1,592 \mathrm{~L}), 75 \%(2,387 \mathrm{~L}), 93 \%(3,183 \mathrm{~L})$, $117 \%(3,979 \mathrm{~L})$, or $140 \%(4,775 \mathrm{~L})$. Irrigation treatments started on 29 May and ended on 19 Oct. and the average irrigation frequency was 12 to 14 times/month over the season. The two harvest dates were 28 Oct. and 25 Nov. The fruit was measured for maturity index at both harvest dates both years (Hermoso et al., 1991). The maturity index scale is from 0 to 7 with the following numbers corresponding to fruit color and maturity level: $0=$ skin color deep green, fruit hard; 1 = skin color yellow-green, fruit starting to soften; 2 = skin with less than half the fruit surface turning red, purple, or black; $3=$ skin color with more than half the surface turning red, purple, or black; $4=$ skin color all purple or black with all white or green flesh; 5 $=$ skin color all purple or black with less than half the flesh turning purple; $6=$ skin color all purple or black with more than half the flesh turning purple; 7 = skin color all purple or black with all the flesh purple to the pit.

Fruit samples were taken to the laboratory and stored in a cold room at $4{ }^{\circ} \mathrm{C}$. Oil was extracted using the Abencor method (Martinez et al., 1975). The fruit was crushed, malaxated, centrifuged, decanted and filtered, then stored in dark glass bottles at $4{ }^{\circ} \mathrm{C}$. The percentage of extractable oil was determined for each sample. The Abencor system estimates the industrial oil yield of large-scale commercial systems, but with small fruit samples. Oil samples were analyzed for free acidity, peroxide value, polyphenol content, oxidative stability (rancimat hours), $\mathrm{K}_{270}, \mathrm{~K}_{232}$, sterol content, and fatty acid composition.

Free fatty acid levels were determined with a potassium hydroxide titration and the peroxide value titration was calculated by the liberation of iodine from potassium iodide. (EEC Reg. N ${ }^{\circ}$ 2568/91-annex II and III). Polyphenol content was determined with a titrimetric reaction (Folin Denis)(Vazquezetal., 1973). Oxidative stability was determined in a rancimat device (Internal method $98{ }^{\circ} \mathrm{C}, 10 \mathrm{~L}$ of air/h). $\mathrm{K}_{270}$ and $\mathrm{K}_{232}$ values (UV absorbance at 270 and $232 \mathrm{~nm}$ ) were determined with spectrophotometer analysis (EEC Reg. № 2568/91-annex IX). Fatty acid composition and sterols were determined by gas chromatography (EEC Reg. $\mathrm{N}^{\circ}$ 2568/91-annex X-A and V).

Each oil, per treatment and replicate, was blindly tasted twice by five tasters on two different dates. The International Olive Oil Council (IOOC) standard sensory profile sheet was used for oil evaluations. It has an intensity rating range from 1 to 10 for fruitiness, bitterness, and pungency. Tasters wrote in descriptors to characterize the olive fruitiness and various undertones such as: woody, nutty, green, herbaceous, grass, artichoke, apple, and other ripe fruits. They also indicated their perception of balance and complexity within each oil. The tasters were trained members of the University of California Olive Oil Tasting Panel, recognized by the IOOC using official IOOC tasting methodologies:(IOOC 1996, 1997). The mean of each tasting session was calculated for each oil for the 21 plots (two samples and three replications/plot). The data were subjected to analysis of variance (ANOVA) and separation of the means was obtained using the least significant difference (LSD).

\section{Results}

The change in fruit color from green to yellow-red-purple-black, as measured by maturity index, declined as the trees received more irrigation water (Table 1). In 2002, the later harvested fruit had a maturity index that was significantly greener in color by a factor of -1.06 from the driest to the wettest trees. In 2003 , both the late and early harvested fruit had significantly less red to purple fruit coloration by a factor of -2.27 and -1.71 respectively, as the amount of irrigation water for the trees increased. The amount of extractable oil from the olives changed significantly according to the amount of irrigation water given to each treatment. In both years the greatest amount of oil was extracted from the second lowest irrigation treatment $(25 \%$ and $33 \%$ ETc). The extractability of the oil from the olives increased slightly with an increase in irrigation

Table 1. Maturity index and oil extraction percentage with the Abencor system for 2002 and 2003, early and late harvested fruit as influenced by irrigation levels $(\% \mathrm{Etc})$.

\begin{tabular}{|c|c|c|c|c|c|c|c|c|c|}
\hline $\begin{array}{l}2002 \\
\text { Treatment } \\
(\% \text { ETc) }\end{array}$ & \multicolumn{2}{|c|}{$\begin{array}{l}\text { Maturity } \\
\text { index (MI) }\end{array}$} & \multicolumn{2}{|c|}{$\begin{array}{c}\text { Oil extraction } \\
\% \text { (Abencor) } \\
\end{array}$} & $\begin{array}{c}2003 \\
\text { Treatment } \\
(\% \text { ETc })\end{array}$ & \multicolumn{2}{|c|}{$\begin{array}{l}\text { Maturity } \\
\text { index (MI) }\end{array}$} & \multicolumn{2}{|c|}{$\begin{array}{l}\text { Oil extraction } \\
\% \text { (Abencor) } \\
\end{array}$} \\
\hline 15 & $1.30 \mathrm{a}^{2}$ & $4.78 \mathrm{a}$ & $19.86 \mathrm{a}$ & $17.09 \mathrm{a}$ & 28 & $3.78 \mathrm{a}$ & $4.65 \mathrm{a}$ & $19.51 \mathrm{a}$ & $8.58 \mathrm{a}$ \\
\hline 25 & $2.01 \mathrm{ab}$ & $4.31 \mathrm{ab}$ & $23.86 \mathrm{~b}$ & $17.37 \mathrm{a}$ & 33 & $3.49 \mathrm{~b}$ & $4.42 \mathrm{a}$ & $20.37 \mathrm{a}$ & $12.41 \mathrm{~b}$ \\
\hline 40 & $2.02 \mathrm{ab}$ & $4.16 \mathrm{abc}$ & $17.65 \mathrm{c}$ & $17.14 \mathrm{a}$ & 55 & $2.84 \mathrm{c}$ & $3.61 \mathrm{~b}$ & $13.10 \mathrm{~b}$ & $11.88 \mathrm{bc}$ \\
\hline 57 & $2.07 \mathrm{~b}$ & $4.14 \mathrm{abc}$ & $14.01 \mathrm{~d}$ & $14.5 \mathrm{~b}$ & 74 & $2.60 \mathrm{c}$ & $2.89 \mathrm{c}$ & $10.65 \mathrm{c}$ & $11.27 \mathrm{bc}$ \\
\hline 107 & $2.68 \mathrm{~b}$ & $3.72 b c$ & $7.11 \mathrm{f}$ & $9.56 \mathrm{c}$ & 140 & $2.07 \mathrm{~d}$ & $2.38 \mathrm{~d}$ & $4.86 \mathrm{e}$ & $9.4 \mathrm{a}$ \\
\hline
\end{tabular}

${ }^{2}$ Different letters indicate that the values are significantly different at $P=0.05$. 
from $15 \%$ to $25 \%$ ETc in 2002 and from $28 \%$ to $33 \%$ ETc in 2003 . It declined significantly, however, as water was provided to the trees at and above the $40 \%$ to $55 \%$ ETc range. For early and late harvested fruit in both 2002 and 2003 , each increase in irrigation treatment percentage lowered the average oil extractability. The greatest percentage of oil was extracted at the earlier harvest dates and was $23.9 \%$ in 2002 and $20.4 \%$ in 2003 . As the amount of irrigation water was increased, the extractability declined to a low of $7.11 \%$ at the early harvest date and to $9.56 \%$ at the late harvest date in 2002 in trees receiving $107 \%$ ETc and down to $4.86 \%$ at the early harvest date and $9.40 \%$ at the late harvest date in trees receiving $140 \%$ ETc in 2003. These were differences in oil extractability of $16.8 \%$ in 2002 and $15.5 \%$ in 2003 for early harvested fruit. For later harvested fruit there was a decline in extractability of $7.8 \%$ in 2002 and $3.0 \%$ in 2003 .

In 2002, as the irrigation level of the olive trees increased, the total polyphenols in the olive oil significantly decreased, particularly at the lower levels of irrigation (Table 2). As irrigation increased from $15 \%$ ETc to $25 \%$ ETc, the level of polyphenols decreased by one-third, and then dropped again by one-third when irrigated at $40 \%$ ETc. Levels of total polyphenols continued to decline in treatments receiving increasing amounts of water, but at a much slower rate. The four highest irrigation treatments $(57 \%, 71 \%, 89 \%$, and $107 \%$ ETc) produced oils that were not significantly different from each other. In 2003, with each increasing irrigation treatment level, there was only one level $(33 \%)$ that showed a significant difference in total polyphenol content and oxidative stability (Table 3 ). Oxidative stability was correlated very closely with the total polyphenol content of the oils, $r^{2}=0.98$ in 2002 and 0.94 in 2003.

UV absorbance in the 270 and $232 \mathrm{~nm}$ spectrum indicates the presence of oxidized compounds. The K-232 absorbance showed only a slight significant difference in both years, and only for the lowest irrigation treatment level. In 2002, the K-270 levels were significantly different between the three lowest irrigation treatment levels, but there was no difference between any of the treatments above $40 \%$ ETc. For 2003, when all the treatments received more water, no significant differences in K-270 levels were observed among any of the treatments. Oil peroxide values in 2002 were different only at the two extremes of irrigation treatment levels and the value was highest from trees receiving the most water. In 2003, similarly, the differences in peroxide value were greatest between the extremes in irrigation levels, but the highest value occurred in the oil made from trees receiving the least amount of irrigation. Free fatty acid (percent oleic) concentrations in oil extracted from fruit on trees that had received higher irrigation rates, were significantly higher in 2002, but showed no significant difference in 2003 even though they were quite different numerically.

The fatty acid composition of olive oils changed slightly with tree irrigation level (Tables 4 and 5). Some of the differences were significant and consistent in both years, but most were not. In 2002, oleic acid was decreased mildly as trees were given more water. Only the lowest two irrigation treatment levels, however, were significantly different from most of the treatments. For the lowest irrigation level, the percentage of oleic fatty acid was the highest by $2.5 \%$. Palmitic acid levels were not affected by irrigation treatment levels. Palmitoleic, linoleic, and linolenic fatty acid levels significantly increased by $62 \%$, $17 \%$, and $6 \%$ respectively, in oils made from trees receiving increased amounts of irrigation. Heptadecanoic, heptadecenoic, and stearic fatty acid levels significantly decreased by $29 \%, 24 \%$, and $21 \%$ respectively, in treatments receiving more water. Mono-unsaturated type fatty acids declined in relation to the poly-unsaturated fatty acids that significantly increased when comparing the lowest $(15 \%$ ETc) irrigation level with treatments of $40 \%$ ETc and above (Table 6). The levels and ratio of saturated and unsaturated fatty acids was unchanged due to irrigation.

In 2003, the only fatty acid showing significant differences similar to the previous year, due to more irrigation, was stearic, which decrease by $50 \%$ (Table 7). Again, the lowest and the highest irrigation levels showed the greatest change. Palmitic, palmitoleic, heptadecanoic, heptadecenoic, oleic, linoleic, linolenic, and arachidic fatty acids did not change significantly due to tree irrigation levels, but gadoleic and behenic fatty acids did. The relative fatty acid composition of oils in 2003 showed no significant differences in the ratio between mono and poly unsaturated or between saturated and unsaturated fatty acids due to tree irrigation levels.

The total sterol content and some individual sterols of olive oils made from trees receiving increasing levels of irrigation, from $15 \%$ to $107 \%$ ETc in 2002 and from $28 \%$ to $140 \%$ ETc in 2003, showed some significant changes both years, but results were not consistent from one year to the next (Table 8 and 9). The total sterol content $\left(\mathrm{mg} \cdot \mathrm{kg}^{-1}\right)$ increased by $25 \%$ in 2002 , but showed no significant change in 2003. The percent cholesterol level decreased in olive oils made from trees that were irrigated more in 2002, but showed no significant difference in 2003. When irrigation levels were compared from very low to very high, the campesterol percentage showed no change in 2002 , but decreased by $0.4 \%$ in 2003 ; the stigmasterol percentage showed no change in 2002 , but increased by $0.33 \%$ in 2003 ; the $\Delta-7$ avenasterol percentage was unchanged in 2002 , but decreased by half in 2003, and the erythrodiol percentage decreased by $2.8 \%$ in 2002 , but did not change significantly in 2003 .

Table 2. Year 2002, total polyphenols, oxidative stability, UV absorbance $\left(\mathrm{K}_{270}-\mathrm{K}_{232}\right)$, peroxide value and free acidity in oils from trees receiving different amounts of irrigation.

\begin{tabular}{|c|c|c|c|c|c|c|}
\hline $\begin{array}{l}\text { Treatment } \\
(\% \text { ETc })\end{array}$ & $\begin{array}{l}\text { Polyphenols } \\
\text { (mg/L.caffeic) }\end{array}$ & $\begin{array}{l}\text { Oxidative } \\
\text { stability } \\
\text { (h) }\end{array}$ & $\mathrm{K}_{270}$ & $\mathrm{~K}_{232}$ & $\begin{array}{c}\text { Peroxide } \\
\text { value } \\
\text { (meq. } \mathrm{O}_{2} / \mathrm{kg} \text { ) }\end{array}$ & $\begin{array}{c}\text { Free } \\
\text { acidity } \\
(\% \text { oleic })\end{array}$ \\
\hline 15 & $432.43 \mathrm{a}$ & $11.36 \mathrm{a}$ & $0.14 \mathrm{a}$ & $1.63 \mathrm{ab}$ & $4.83 \mathrm{a}$ & $0.13 \mathrm{a}$ \\
\hline 25 & $275.30 \mathrm{~b}$ & $8.83 \mathrm{~b}$ & $0.10 \mathrm{~b}$ & $1.46 \mathrm{~b}$ & $4.20 \mathrm{a}$ & $0.23 \mathrm{a}$ \\
\hline 40 & $165.16 \mathrm{c}$ & $5.44 \mathrm{c}$ & $0.08 \mathrm{c}$ & $1.36 \mathrm{~b}$ & $3.80 \mathrm{a}$ & $0.31 \mathrm{ab}$ \\
\hline 57 & $102.97 \mathrm{~cd}$ & $4.76 \mathrm{~cd}$ & $0.08 \mathrm{c}$ & $1.52 \mathrm{~b}$ & $3.67 \mathrm{a}$ & $0.61 \mathrm{c}$ \\
\hline 71 & $98.20 \mathrm{~cd}$ & $4.61 \mathrm{~cd}$ & $0.07 \mathrm{c}$ & $1.50 \mathrm{~b}$ & $3.53 \mathrm{a}$ & $0.61 \mathrm{c}$ \\
\hline 89 & $64.30 \mathrm{~d}$ & $4.39 \mathrm{~cd}$ & $0.07 \mathrm{c}$ & $1.60 \mathrm{~b}$ & $4.23 \mathrm{a}$ & $0.55 \mathrm{bc}$ \\
\hline 107 & $53.30 \mathrm{~d}$ & $3.26 \mathrm{~d}$ & $0.08 \mathrm{c}$ & $2.08 \mathrm{~b}$ & $8.93 \mathrm{~b}$ & $0.58 \mathrm{c}$ \\
\hline
\end{tabular}

${ }^{2}$ Different letters indicate that the values are significantly different at $P=0.05$.

Table 3. Year 2003, total polyphenols, oxidative stability, UV absorbance $\left(\mathrm{K}_{270}-\mathrm{K}_{232}\right)$, peroxide value and free acidity in oils from trees receiving different amounts of irrigation.

\begin{tabular}{|c|c|c|c|c|c|c|}
\hline $\begin{array}{l}\text { Treatment } \\
(\% \text { ETc })\end{array}$ & $\begin{array}{l}\text { Polyphenols } \\
\text { (mg/L.caffeic) }\end{array}$ & $\begin{array}{l}\text { Oxidative } \\
\text { stability } \\
\text { (h) }\end{array}$ & $\mathrm{K}_{270}$ & $\mathrm{~K}_{232}$ & $\begin{array}{c}\text { Peroxide } \\
\text { value } \\
\text { (meq. } \mathrm{O}_{2} / \mathrm{kg} \text { ) }\end{array}$ & $\begin{array}{c}\text { Free } \\
\text { acidity } \\
\text { (\% oleic) }\end{array}$ \\
\hline 28 & $85.0 \mathrm{a}^{\mathrm{z}}$ & $31.2 \mathrm{a}$ & $0.13 \mathrm{a}$ & $2.0 \mathrm{a}$ & $9.0 \mathrm{a}$ & $0.13 \mathrm{a}$ \\
\hline 74 & $74.7 \mathrm{a}$ & $25.6 \mathrm{a}$ & $0.13 \mathrm{a}$ & $1.4 \mathrm{c}$ & $4.0 \mathrm{c}$ & $0.57 \mathrm{a}$ \\
\hline 93 & $97.3 \mathrm{a}$ & $25.9 \mathrm{a}$ & $0.12 \mathrm{a}$ & $1.4 \mathrm{c}$ & $4.0 \mathrm{c}$ & $0.97 \mathrm{a}$ \\
\hline 117 & $78.3 \mathrm{a}$ & $23.6 \mathrm{a}$ & $0.13 \mathrm{a}$ & $1.4 \mathrm{c}$ & $4.4 \mathrm{bc}$ & $1.90 \mathrm{a}$ \\
\hline
\end{tabular}

${ }^{2}$ Different letters indicate that the values are significantly different at $P=0.05$. 
The $\beta$-sitosterol, and $\Delta-7$ stigmasterol levels were unchanged due to irrigation treatment in both years.

In 2002 , the oil made from $15 \%$ ETc irrigated trees had the highest flavor intensity of all the treatments for fruitiness (3.6), bitterness (6.0), and pungency (4.9) (Table 10). The flavor was therefore unbalanced, very woody, strongly herbaceous, green, extremely bitter, very pungent, and lacking in complexity. The oil made from trees receiving slightly more water $(25 \% \mathrm{ETc})$ was less intense in all attributes, with a fruitiness of (3.2), and significantly less bitterness (4.2) and pungency (3.9), but was still unbalanced. This oil was characterized as slightly woody, herbaceous, green, and lacking complexity. The intermediate irrigation levels (40\% and 57\% ETc) produced olive oils with fairly high fruitiness (2.7 and 2.6 respectively) that was greater in intensity than the bitterness (1.7 and 0.93 respectively), and pungency (1.9 and 1.1 respectively). They both were balanced oils. The oil made from $40 \%$ ETc irrigated trees was complex, with the taste panel members indicating that it had very pleasing characteristics of artichoke, green apple, grass, nuts, and undertones of some other ripe fruits. The oil from $57 \%$ ETc irrigated trees, had almost the same intensity of fruitiness as the $40 \%$ ETc oil, but significantly less bitterness and pungency. Bitterness and pungency were reduced more by this level of irrigation than was fruitiness.
The oil was characterized as slightly grassy with a complexity of ripe olive fruit flavors and undertones of green apple and artichoke. The oils made from trees that received the most water (irrigated at or above the $71 \%$ ETc level), had very little bitterness or pungency (below 0.3 for both), but also had significantly less fruitiness intensity (2.1 to 1.7 ) than the lower irrigation treatment levels. The oils made from olives on trees that were irrigated at the $71 \%, 87 \%$, and $107 \%$ ETc levels were almost indistinguishable from each other. They were all characterized as being bland, with a very mild ripe olive fruit flavor. They were balanced, but lacked complexity.

In 2003, the most intensely flavored and

Table 4. Year 2002, fatty acid composition in oils from trees receiving different amounts of irrigation.

\begin{tabular}{|c|c|c|c|c|c|c|c|}
\hline \multirow[b]{2}{*}{ Fatty acids, $\%$} & \multicolumn{7}{|c|}{$\operatorname{ETc}(\%)$} \\
\hline & 15 & 25 & 40 & 57 & 71 & 89 & 107 \\
\hline Palmitic $\left(\mathrm{C}_{16: 0}\right)$ & $15.00 \mathrm{a}^{\mathrm{z}}$ & $15.50 \mathrm{a}$ & $15.90 \mathrm{a}$ & $15.90 \mathrm{a}$ & $16.00 \mathrm{a}$ & $16.10 \mathrm{a}$ & $15.70 \mathrm{a}$ \\
\hline Palmitoleic $\left(\mathrm{C}_{16: 1}\right)$ & $1.30 \mathrm{a}$ & $1.24 \mathrm{a}$ & $1.63 \mathrm{~b}$ & $1.65 \mathrm{~b}$ & $1.87 \mathrm{bc}$ & $1.99 \mathrm{c}$ & $2.08 \mathrm{c}$ \\
\hline Heptadecanoic $\left(\mathrm{C}_{170}\right)$ & $0.14 \mathrm{a}$ & $0.15 \mathrm{~b}$ & $0.12 \mathrm{c}$ & $0.11 \mathrm{~cd}$ & $0.10 \mathrm{~d}$ & $0.10 \mathrm{~d}$ & $0.10 \mathrm{~d}$ \\
\hline Heptadecenoic $\left(\mathrm{C}_{17: 1}\right)$ & $0.34 \mathrm{a}$ & $0.34 \mathrm{a}$ & $0.29 \mathrm{~b}$ & $0.27 \mathrm{c}$ & $0.26 \mathrm{c}$ & $0.27 \mathrm{c}$ & $0.26 \mathrm{c}$ \\
\hline Stearic $\left(\mathrm{C}_{18: 0}\right)$ & $1.97 \mathrm{a}$ & 1.99 a & $1.72 \mathrm{~b}$ & $1.69 \mathrm{~b}$ & $1.59 \mathrm{c}$ & $1.56 \mathrm{c}$ & $1.55 \mathrm{c}$ \\
\hline Oleic $\left(\mathrm{C}_{18.1}\right)$ & $69.40 \mathrm{a}$ & $67.80 \mathrm{ab}$ & $65.70 \mathrm{bc}$ & $66.20 \mathrm{bc}$ & $65.60 \mathrm{bc}$ & $65.30 \mathrm{c}$ & $66.10 \mathrm{bc}$ \\
\hline Linoleic $\left(\mathrm{C}_{18 \cdot 2}\right)$ & $10.40 \mathrm{a}$ & $11.50 \mathrm{ab}$ & $13.00 \mathrm{~b}$ & $12.70 \mathrm{~b}$ & $13.10 \mathrm{~b}$ & $13.10 \mathrm{~b}$ & $12.50 \mathrm{~b}$ \\
\hline Linolenic $\left(\mathrm{C}_{18 \cdot 3}\right)$ & $0.67 \mathrm{ab}$ & $0.64 \mathrm{c}$ & $0.65 \mathrm{bc}$ & $0.66 \mathrm{bc}$ & $0.69 \mathrm{a}$ & $0.71 \mathrm{~d}$ & $0.71 \mathrm{~d}$ \\
\hline Arachidic $\left(\mathrm{C}_{20: 0}\right)$ & $0.40 \mathrm{a}$ & $0.40 \mathrm{a}$ & $0.37 \mathrm{bc}$ & $0.37 \mathrm{bc}$ & $0.37 \mathrm{bc}$ & $0.36 \mathrm{a}$ & $0.40 \mathrm{a}$ \\
\hline Gadoleic $\left(\mathrm{C}_{20: 1}\right)$ & $0.30 \mathrm{a}$ & $0.31 \mathrm{a}$ & $0.30 \mathrm{a}$ & $0.31 \mathrm{a}$ & $0.30 \mathrm{a}$ & $0.30 \mathrm{a}$ & $0.32 \mathrm{a}$ \\
\hline Behenic $\left(\mathrm{C}_{22.0}\right)$ & $0.12 \mathrm{a}$ & $0.12 \mathrm{a}$ & $0.14 \mathrm{a}$ & $0.12 \mathrm{a}$ & $0.13 \mathrm{a}$ & $0.11 \mathrm{a}$ & $0.12 \mathrm{a}$ \\
\hline
\end{tabular}

${ }^{2}$ Different letters indicate that the values are significantly different at $P=0.05$.

Table 5. Year 2003, fatty acid composition in oils from trees receiving different amounts of irrigation.

\begin{tabular}{|c|c|c|c|c|c|c|c|}
\hline \multirow[b]{2}{*}{ Fatty acids } & \multicolumn{7}{|c|}{ ETc $(\%)$} \\
\hline & 28 & 33 & 55 & 74 & 93 & 117 & 140 \\
\hline Palmitic $\left(\mathrm{C}_{16.0}\right)$ & $15.80 \mathrm{a}^{\mathrm{z}}$ & $15.80 \mathrm{a}$ & $15.70 \mathrm{a}$ & $15.80 \mathrm{a}$ & $15.10 \mathrm{a}$ & $15.30 \mathrm{a}$ & $15.10 \mathrm{a}$ \\
\hline Palmitoleic $\left(\mathrm{C}_{16.1}\right)$ & $1.30 \mathrm{a}$ & $1.50 \mathrm{a}$ & $1.50 \mathrm{a}$ & $1.60 \mathrm{a}$ & $1.60 \mathrm{a}$ & $1.50 \mathrm{a}$ & $1.50 \mathrm{a}$ \\
\hline Heptadecanoic $\left(\mathrm{C}_{17: 0}\right)$ & $0.20 \mathrm{a}$ & $0.20 \mathrm{a}$ & $0.17 \mathrm{a}$ & $0.40 \mathrm{a}$ & $0.17 \mathrm{a}$ & $0.13 \mathrm{a}$ & $0.13 \mathrm{a}$ \\
\hline Heptadecenoic $\left(\mathrm{C}_{17.1}\right)$ & $0.43 \mathrm{a}$ & $0.40 \mathrm{a}$ & $0.37 \mathrm{a}$ & $0.37 \mathrm{a}$ & $0.33 \mathrm{a}$ & $0.33 \mathrm{a}$ & $0.33 \mathrm{a}$ \\
\hline Stearic $\left(\mathrm{C}_{18: 0}\right)$ & $2.30 \mathrm{a}$ & $2.10 \mathrm{ab}$ & $1.90 \mathrm{bc}$ & $1.80 \mathrm{bc}$ & $1.77 \mathrm{~cd}$ & $1.77 \mathrm{~cd}$ & $1.53 \mathrm{~d}$ \\
\hline Oleic $\left(\mathrm{C}_{18: 1}\right)$ & $67.10 \mathrm{a}$ & $66.50 \mathrm{a}$ & $66.90 \mathrm{a}$ & $66.90 \mathrm{a}$ & $67.70 \mathrm{a}$ & $67.80 \mathrm{a}$ & $67.90 \mathrm{a}$ \\
\hline Linoleic $\left(\mathrm{C}_{18.2}\right)$ & $10.90 \mathrm{a}$ & $11.80 \mathrm{a}$ & $11.80 \mathrm{a}$ & $11.60 \mathrm{a}$ & $11.60 \mathrm{a}$ & $11.30 \mathrm{a}$ & $11.40 \mathrm{a}$ \\
\hline Linolenic $\left(\mathrm{C}_{18: 3}\right)$ & $0.87 \mathrm{a}$ & $0.77 \mathrm{ab}$ & $0.73 \mathrm{~b}$ & $0.77 \mathrm{ab}$ & $0.83 \mathrm{ab}$ & $0.87 \mathrm{a}$ & $0.87 \mathrm{a}$ \\
\hline Arachidic $\left(\mathrm{C}_{20: 0}\right)$ & $0.40 \mathrm{a}$ & $0.40 \mathrm{a}$ & $0.43 \mathrm{a}$ & $0.40 \mathrm{a}$ & $0.40 \mathrm{a}$ & $0.40 \mathrm{a}$ & $0.43 \mathrm{a}$ \\
\hline Gadoleic $\left(\mathrm{C}_{20: 1}\right)$ & $0.30 \mathrm{a}$ & $0.30 \mathrm{a}$ & $0.30 \mathrm{a}$ & $0.30 \mathrm{a}$ & $0.33 \mathrm{ab}$ & $0.40 \mathrm{c}$ & $0.37 \mathrm{bc}$ \\
\hline Behenic $\left(\mathrm{C}_{22: 0}\right)$ & $0.10 \mathrm{a}$ & $0.10 \mathrm{a}$ & $0.13 \mathrm{ab}$ & $0.17 \mathrm{bc}$ & $0.20 \mathrm{c}$ & $0.17 \mathrm{bc}$ & $0.20 \mathrm{c}$ \\
\hline
\end{tabular}

${ }^{2}$ Different letters indicate that the values are significantly different at $P=0.05$.

Table 6. Year 2002, fatty acids - relative composition in oils from trees receiving different amounts of irrigation.

\begin{tabular}{|c|c|c|c|c|c|c|c|}
\hline Treatment & Mono-unsaturated & Poly-unsaturated & Unsaturated & Saturated & $\begin{array}{l}\text { Oleic- } \\
\text { linolec }\end{array}$ & $\begin{array}{l}\text { Unsaturated- } \\
\text { saturated }\end{array}$ & $\begin{array}{l}\text { Mono-unsaturated- } \\
\text { poly-unsaturated }\end{array}$ \\
\hline $15 \%$ ETc & $71.35 \mathrm{a}$ & $11.03 \mathrm{a}$ & $82.38 \mathrm{a}$ & $17.60 \mathrm{a}$ & $7.10 \mathrm{a}$ & $4.69 \mathrm{a}$ & $6.53 \mathrm{a}$ \\
\hline $25 \%$ ETc & $69.69 \mathrm{ab}$ & $12.14 \mathrm{ab}$ & $81.83 \mathrm{a}$ & $18.16 \mathrm{a}$ & $6.06 \mathrm{ab}$ & $4.51 \mathrm{a}$ & $5.75 \mathrm{ab}$ \\
\hline $40 \%$ ETc & $67.93 \mathrm{~b}$ & $13.69 \mathrm{~b}$ & $81.62 \mathrm{a}$ & $18.34 \mathrm{a}$ & $5.37 \mathrm{~b}$ & $4.45 \mathrm{a}$ & $4.98 \mathrm{~b}$ \\
\hline $57 \%$ ETc & $68.45 \mathrm{~b}$ & $13.36 \mathrm{~b}$ & $81.82 \mathrm{a}$ & $18.16 \mathrm{a}$ & $5.13 \mathrm{~b}$ & $4.51 \mathrm{a}$ & $5.18 \mathrm{~b}$ \\
\hline $71 \%$ ETc & $68.08 \mathrm{~b}$ & $13.74 \mathrm{~b}$ & $81.81 \mathrm{a}$ & $18.15 \mathrm{a}$ & $5.23 \mathrm{~b}$ & $4.51 \mathrm{a}$ & $4.97 \mathrm{~b}$ \\
\hline $89 \%$ ETc & $67.86 \mathrm{~b}$ & $13.80 \mathrm{~b}$ & $81.67 \mathrm{a}$ & $18.20 \mathrm{a}$ & $5.06 \mathrm{~b}$ & $4.49 \mathrm{a}$ & $4.94 \mathrm{~b}$ \\
\hline $107 \%$ ETc & $68.77 \mathrm{~b}$ & $13.17 \mathrm{~b}$ & $81.95 \mathrm{a}$ & $17.87 \mathrm{a}$ & $5.00 \mathrm{~b}$ & $4.59 \mathrm{a}$ & $5.23 \mathrm{~b}$ \\
\hline
\end{tabular}

Different letters indicate that the values are significantly different at $P=0.05$.

Table 7. Year 2003, fatty acid relative composition in oils from trees receiving different amounts of irrigation.

\begin{tabular}{|c|c|c|c|c|c|c|c|}
\hline Treatment & Mono-unsaturated & Poly-unsaturated & Unsaturated & Saturated & $\begin{array}{l}\text { Oleic- } \\
\text { linolec }\end{array}$ & $\begin{array}{c}\text { Unsaturated- } \\
\text { saturated }\end{array}$ & $\begin{array}{c}\text { Mono-unsaturated- } \\
\text { poly-unsaturated }\end{array}$ \\
\hline $28 \%$ ETc & $69.17 \mathrm{a}$ & $11.80 \mathrm{a}$ & $80.97 \mathrm{a}$ & $18.73 \mathrm{a}$ & $6.14 \mathrm{a}$ & $4.33 \mathrm{a}$ & $5.86 \mathrm{a}$ \\
\hline $33 \%$ ETc & $68.73 \mathrm{a}$ & $12.60 \mathrm{a}$ & $81.33 \mathrm{a}$ & $18.50 \mathrm{a}$ & $5.64 \mathrm{a}$ & $4.39 \mathrm{a}$ & $5.47 \mathrm{a}$ \\
\hline $55 \%$ ETc & $69.07 \mathrm{a}$ & $12.53 \mathrm{a}$ & $81.60 \mathrm{a}$ & $18.17 \mathrm{a}$ & $5.68 \mathrm{a}$ & $4.50 \mathrm{a}$ & $5.51 \mathrm{a}$ \\
\hline $74 \%$ ETc & $69.17 \mathrm{a}$ & $12.40 \mathrm{a}$ & $81.57 \mathrm{a}$ & $18.40 \mathrm{a}$ & $5.76 \mathrm{a}$ & $4.43 \mathrm{a}$ & $5.58 \mathrm{a}$ \\
\hline $93 \%$ ETc & $69.80 \mathrm{a}$ & $12.47 \mathrm{a}$ & $82.27 \mathrm{a}$ & $17.40 \mathrm{a}$ & $5.83 \mathrm{a}$ & $4.75 \mathrm{a}$ & $5.62 \mathrm{a}$ \\
\hline $117 \%$ ETc & $70.03 \mathrm{a}$ & $12.17 \mathrm{a}$ & $82.20 \mathrm{a}$ & $17.60 \mathrm{a}$ & $6.00 \mathrm{a}$ & $4.67 \mathrm{a}$ & $5.76 \mathrm{a}$ \\
\hline $140 \%$ ETc & $70.07 \mathrm{a}$ & $12.27 \mathrm{a}$ & $82.30 \mathrm{a}$ & $17.23 \mathrm{a}$ & $5.99 \mathrm{a}$ & $4.78 \mathrm{a}$ & $5.74 \mathrm{a}$ \\
\hline
\end{tabular}

Different letters indicate that the values are significantly different at $P=0.05$. 
Table 8. Year 2002, sterol composition of oils from the least and most irrigated trees.

\begin{tabular}{lrr}
\hline Sterols & \multicolumn{1}{c}{$15 \%$ ETc } & $107 \%$ ETc \\
\hline Total $\left(\mathrm{mg}^{\circ} \mathrm{kg}^{-1}\right)$ & $1,265.00 \mathrm{a}^{z}$ & $1,577.30 \mathrm{~b}$ \\
Cholesterol (\%) & $0.29 \mathrm{a}$ & $0.12 \mathrm{~b}$ \\
Campesterol (\%) & $3.46 \mathrm{a}$ & $3.48 \mathrm{a}$ \\
Stigmasterol (\%) & $0.93 \mathrm{a}$ & $0.89 \mathrm{a}$ \\
$\beta$-sitosterol (\%) & $94.79 \mathrm{a}$ & $94.95 \mathrm{a}$ \\
$\Delta-7$ stigmasterol (\%) & $0.14 \mathrm{a}$ & $0.13 \mathrm{a}$ \\
$\Delta-7$ avenasterol (\%) & $0.39 \mathrm{a}$ & $0.42 \mathrm{a}$ \\
Erythrodiol (\%) & $3.65 \mathrm{a}$ & $0.84 \mathrm{~b}$ \\
\hline
\end{tabular}

${ }^{2}$ Different letters indicate that the values are significantly different at $P=0.05$.

Table 9. Year 2003, sterol composition of oils from the least and most irrigated trees.

\begin{tabular}{lrr}
\hline Sterols & \multicolumn{1}{c}{$28 \%$ ETc } & $140 \%$ ETc \\
\hline Total $\left({\left.\mathrm{mg} \cdot \mathrm{kg}^{-1}\right)}^{2,190.00 \mathrm{a}^{\mathrm{z}}}\right.$ & $2,072.00 \mathrm{a}$ \\
Cholesterol (\%) & $0.10 \mathrm{a}$ & $0.20 \mathrm{a}$ \\
Campesterol (\%) & $4.33 \mathrm{a}$ & $3.97 \mathrm{~b}$ \\
Stigmasterol (\%) & $0.77 \mathrm{a}$ & $1.10 \mathrm{~b}$ \\
$\beta$-sitosterol (\%) & $3.60 \mathrm{a}$ & $93.80 \mathrm{a}$ \\
$\Delta-7$ stigmasterol (\%) & $0.40 \mathrm{a}$ & $0.37 \mathrm{a}$ \\
$\Delta-7$ avenasterol (\%) & $0.63 \mathrm{a}$ & $0.27 \mathrm{~b}$ \\
Erythrodiol (\%) & $2.40 \mathrm{a}$ & $2.80 \mathrm{a}$ \\
\hline
\end{tabular}

${ }^{2}$ Different letters indicate that the values are significantly different at $P=0.05$.

balanced oils were made from trees at the lower irrigation levels (28\% and 33\% ETc) (Table 11). Fruitiness (4.2 and 4.1 respectively) was not significantly different at these irrigation levels. Bitterness and pungency were significantly different, however. In oils made from trees irrigated at $28 \%$ and $33 \%$ ETc, bitterness dropped almost half from 1.6 to 0.96 and pungency dropped from 2.8 to 1.9 . These oils were characterized as very fruity, balanced, and complex with both green and ripe fruit flavors. Trees receiving 55\% and $74 \%$ ETc produced oils that were intermediate in fruitiness (3.2 and 2.8 respectively), but very low in bitterness ( 0.47 and 0.28 respectively) and pungency ( 1.1 and 0.63 respectively). They were characterized as unbalanced. Fruitiness, bitterness and pungency were all very low in 2003 in all of the three highest irrigation level treated trees ( $93 \%$ to $149 \%$ ETc). These oils were described by the taste panel members as having mild ripe fruit flavor, but as unbalanced due to an almost complete lack of bitterness and pungency.

\section{Discussion}

A water management strategy for oil olive production to optimize yield, control the amount of shoot growth, maintain tree size, reduce alternate bearing, or affect any other horticultural parameter, must take into consideration the ultimate effect on oil quality. The data from this work needs to be evaluated in combination with all of the horticultural factors that lead to annual bearing of heavy crops and good oil extraction that are also influenced by irrigation. Ultimately, these influences must be balanced, taking into account such economic factors as water costs, tree management, and harvest costs in order to apply the best possible irrigation strategy to each orchard. This study in a super-high-density Arbequina orchard, demonstrated that the quantity of water applied to trees has a profound influence on olive oil quality very similar to results by other researchers (d'Andria et al., 2002; Faci et al., 2002; Gucci et al., 2004; Salas et al., 1997; Tovar et al., 2002). It also showed that increased water applied to trees receiving the lower levels of irrigation (under irrigated) had a strong yet generally negative influence on both the chemical and sensory properties of the oil, more so than did increases in water applied to well irrigated trees. Producers who want to optimize oil production, which is a function of fruit yield and oil extraction, need to take into account the benefits of moderate water status and be aware that excessive irrigation can dramatically reduce the oil yield (extraction) from the fruit. They also need to consider that optimum oil sensory characteristics are achieved with moderate water stress.

The traditional parameters used to evaluate oil quality such as peroxide value and free acidity were only slightly affected by tree irrigation levels and that was only when comparing the extremes (least and most irrigated treatments). This makes sense since it is well known that these indices of quality are mostly affected by fruit handling and paste manipulation. (Alba
2001 and Hermoso 1991). UV absorbance $\left(\mathrm{K}_{270}\right.$ and $\mathrm{K}_{232}$ ) of oils that were differentially irrigated were only affected by irrigation at the low to moderate levels. None of the irrigation treatments had enough of an effect on the oils to take them out of the category of extra virgin under International Olive Oil Council (IOOC) standards. The quality parameters of total polyphenol content and oxidative stability, which are closely linked, are shown to be dramatically affected by tree irrigation level. The more water trees are given above the low to moderate irrigation levels, the more likely the oils will have a significant reduction in polyphenol content and subsequent reduction in stability. Since these compounds are mostly water soluble, it is not surprising that the water status of the tree and its fruit have an influence on the amount of polyphenols remaining in the oil after processing.

The effect of differential irrigation levels had a mild effect on some fatty acids and some sterols, but from a practical perspective, those changes did not adversely affect quality or take the oils out of the extra virgin category by IOOC standards. Sterols and fatty acid content is used primarily to identify food fraud from improperly labeled, adulterated mixtures of different types of seed, refined, or pomace oils blended with extra virgin olive oil. The amount of irrigation water applied to trees should not have any negative effect on these parameters. The inconsistent results between years would indicate that other, unknown variables may be more relevant than water status in affecting these parameters.

The typically mild-flavor characteristics associated with Arbequina olive oil can be exaggerated with increasing amounts of irrigation water to a point where the oil becomes bland, flat, and one dimensional. Low to moderately irrigated trees, however, produce complex oils that are fruitier with a balance of bitterness and pungency, without any of the harsh woody characteristics of oil produced from under irrigated or drought stressed trees. Intensity of fruitiness, bitterness, and pungency, the three primary positive attributes of olive oil, were all higher in trees receiving low to moderate

Table 10. Year 2002, means of fruitiness, bitterness, and pungency in oils from trees receiving different amounts of irrigation.

\begin{tabular}{|c|c|c|c|c|}
\hline Treatment & Fruitiness & Bitterness & Pungency & Description \\
\hline $15 \%$ ETc & $3.60 \mathrm{~A}^{\mathrm{z}}$ & $6.00 \mathrm{~A}$ & $4.90 \mathrm{~A}$ & Fruity, very woody, herbaceous, and pungent. Extremely bitter. Unbalanced \\
\hline $25 \%$ ETc & $3.20 \mathrm{~A}$ & $4.20 \mathrm{~B}$ & $3.90 \mathrm{~B}$ & Fruity, woody, herbaceous, bitter, and pungent. Green and lacking complexity. \\
\hline $40 \%$ ETc & $2.70 \mathrm{~B}$ & $1.70 \mathrm{C}$ & $1.90 \mathrm{C}$ & Fruity, balanced, and complex. Artichoke, green apple, grassy, nutty, and other ripe fruit. \\
\hline $57 \%$ ETc & $2.60 \mathrm{~B}$ & $0.93 \mathrm{D}$ & $1.10 \mathrm{D}$ & Fruity and balanced. Slight grassy, complex ripe fruits, artichoke, and green apple. \\
\hline $71 \%$ ETc & $2.10 \mathrm{C}$ & $0.30 \mathrm{D}$ & $0.30 \mathrm{E}$ & Mild ripe fruit to bland. Not bitter or pungent \\
\hline $89 \%$ ETc & $1.80 \mathrm{C}$ & $0.22 \mathrm{D}$ & $0.22 \mathrm{E}$ & Mild ripe fruit to bland. Not bitter or pungent \\
\hline $107 \%$ ETc & $1.70 \mathrm{C}$ & $0.20 \mathrm{D}$ & $0.20 \mathrm{E}$ & Mild ripe fruit to bland. Not bitter or pungent \\
\hline
\end{tabular}

${ }^{\mathrm{z}}$ Different letters indicate that the values are significantly different at $P=0.01$.

Table 11. Year 2003, means of fruitiness, bitterness, and pungency in oils from trees receiving different amounts of irrigation.

\begin{tabular}{|c|c|c|c|c|}
\hline Treatment & Fruitiness & Bitterness & Pungency & Description \\
\hline $28 \%$ ETc & $4.20 \mathrm{~A}^{\mathrm{z}}$ & $1.60 \mathrm{~A}$ & $2.80 \mathrm{~A}$ & Very fruity, some bitterness and pungency. Balanced. Herbaceous, grassy, green apple, nettle, and artichoke. \\
\hline $33 \%$ ETc & $4.10 \mathrm{~A}$ & $0.96 \mathrm{~B}$ & $1.90 \mathrm{~B}$ & Very fruity, slightly bitter and pungent. Herbaceous, ripe fruits, and complex. \\
\hline $55 \%$ ETc & $3.20 \mathrm{~B}$ & $0.47 \mathrm{C}$ & $1.10 \mathrm{C}$ & Fruity with both green and ripe fruit flavors. Non bitter. Slight pungency. Unbalanced \\
\hline $74 \%$ ETc & $2.80 \mathrm{BC}$ & $0.28 \mathrm{C}$ & $0.63 \mathrm{CD}$ & Fruity with mild ripe fruit flavors. Not bitter or pungent. Unbalanced. \\
\hline $93 \%$ ETc & $2.50 \mathrm{CD}$ & $0.28 \mathrm{C}$ & $0.44 \mathrm{CD}$ & Mildly fruity with ripe fruit flavors. Not bitter or pungent. Unbalanced. \\
\hline $117 \%$ ETc & $2.00 \mathrm{D}$ & $0.24 \mathrm{C}$ & $0.36 \mathrm{D}$ & Mildly fruity with ripe fruit flavors. Not bitter or pungent. Unbalanced. \\
\hline $140 \%$ ETc & $2.10 \mathrm{D}$ & $0.24 \mathrm{C}$ & $0.29 \mathrm{D}$ & Mildly fruity mild ripe fruit flavors. Not bitter or pungent. Unbalanced. \\
\hline
\end{tabular}

${ }^{\mathrm{z}}$ Different letters indicate that the values are significantly different at $P=0.01$. 
amounts of irrigation water in both years. With the increase in water given to all the irrigation treatments in the second year to encourage greater tree growth, the overall effect was to moderate the bitterness and pungency, without adversely affecting fruitiness. Fruitiness was in fact higher the second year under all irrigation levels compared to the first year. This may lead to a recommendation of increasing water application rates in an effort to reduce these two flavor components and still maintain a high level of fruitiness. If, however, a producer wanted to increase the intensity of bitterness and pungency, they might choose to limit water applications. Care should be taken however to not under irrigate trees and produce unbalanced oils with both bitterness and pungency that is high relative to fruitiness, or to produce oils with less appealing woody flavors.

Regarding oil quality, it seems that an ideal irrigation program under our experimental conditions would be to provide a sustained season-long irrigation deficit of about $33 \%$ to $40 \%$ ETc, to achieve good oil extractability from the olives and to maintain excellent oil chemical parameters, flavor, and stability. Future research work should focus on controlled deficit irrigation near these general levels with modifications to timing and frequency. Irrigation effects on per hectare yield, growth, and return bloom must also be considered. This is the subject of a companion paper submitted by the authors.

\section{Literature Cited}

Alba Mendoza,J.2001. Elaboración de aceite de oliva virgen, p. 551-587. In ElCultivo del Olivo. 4thed. Ediciones Mundi-Prensa. Madrid, Spain.

Beede, R.H. and D.A. Goldhamer. 1994. Olive irrigation management, p. 61-68. In: L. Ferguson, G.S.
Sibbett, and G.CMartin (eds.). Olive production manual. Univ. Calif. DANR Publ. 3353.

Beltrán, G., A. Jiménez, and M. Uceda. 1995. Efecto del régimen hídrico de cultivo sobre la fracción fenólica del aceite de oliva de la variedad Arbequina. Actas del primer Simposio del Olivo Arbequina en Cataluñía. Borjas Blancas. p. $153-155$.

Berenguer, M.J., S. R. Grattan, J.H. Connell, V.S. Polito, and P.M. Vossen. 2004. Irrigation management to optimize olive oil production and quality. Acta Hort. (ISHS) 664:79-85

d'Andria, R. and G. Morelli. 2002. Irrigation regime affects yield and oil quality of olive trees. Acta Hort. (ISHS) 586:273-276

European Union Regulation EEC/2568/91. 1991. The characteristics of olive oils and of oils of olive residue and their analytical methods. Off. F. Euro. Commun. L248:1-82.

Faci, J.M., M.J. Berenguer, J.L. Espada, and S. Garcia. 2002. Effect of variable water irrigation supply in olive (Olea europaea L.) cv. Arbequina in Aragon (Spain). II. Extra virgin oil quality parameters. Acta Hort. (ISHS) 586:341-344.

Fereres, E. and J.R. Castel. 1981. Drip irrigation management. Division of Agricultural Sciences, Univ. Calif. Publ. Lfit. 21259.

Girona, J., M. Luna, A. Arbonés, M. Mata, J. Rufat, and J. Marsal. 2002. Young olive trees responses (Olea europae, cv. 'Arbequina') to different water supplies. Water function determination. Acta Hort. (ISHS) 586:277-280

Goldhamer, D., J. Dunai, and L. Ferguson. 1994. Irrigation requirements of olive trees and responses to sustained deficit irrigation. Acta Hort. (ISHS) 356:172-176.

Gucci, R., M. Servili, S. Esposto, and R. Selvaggini. 2004. Oil quality of olive cv. 'Leccino' grown under irrigated or dry-farmed conditions. Acta Hort. (ISHS) 664:297-302

Ismail, A.S., J. Metzidakis, and G. Stavroulakis. 1999. Effect of irrigation on the quality characteristics of organic olive oil. Acta Hort. (ISHS) 474:687-690.
Hermoso Fernández, M., M. Uceda,A. García-Ortiz, J. Morales, L. Frías, and A. Fernández. 1991. Elaboración de aceite de oliva de calidad. Manual from the Estación de Olivicultura y Elaiotecnia. Finca "Venta del Llano" Mengíbar (Jaén) Spain. Junta de Andalucía vol. 5/91.

Inglese, P., E. Barone, and G. Gullo. 1996. The effect of complementary irrigation on fruit growth, ripening pattern and oil characteristics of olive (Olea europaea L.) cv. Carolea. J. Hort. Sci. 71:257-263.

International Olive Oil Council (IOOC). 1996. General methodology for the organoleptic assessment of virgin olive oil. IOOC standard procedure-COI/T.20/Doc. No 13.

International Olive Oil Council(IOOC). 1997. IOOC RES-4/76-IV/97. Certificate for the recognition of olive oil taste panels.

Lavee, S., M. Nashef, M. Wodner, and H. Harshemesh. 1990. The effect of complementary irrigation added to old olive trees (Olea europaea L.) cv. Souri on fruit characteristics, yield and oil production. Adv. Hort. Sci. 4:135-138.

Martínez, J. M., E. Muñoz, J. Alba, and A. Lanzón. 1975. Informe sobre utilización del analizador de muestras Abencor. Grasas y Aceites 26:379-385.

Moriana, A., F. Orgaz, M. Pastor, and E. Federes. 2003. Yield responses of a mature olive orchard to water deficits. J. Amer. Soc. Hort. Sci. 128:425-431.

Salas, J., M. Pastor, J. Castro, and V. Vega. 1997. Influencia del riego sobre la composición y características organolépticas del aceite de oliva. Grasas y Aceites 48, 2:74-82.

Tovar, M.J., Romero, M.P., Alegre, S., Girona, J., and Motilva, M.J. 2002. Composition and organoleptic characteristics of oil from Arbequina olive (Olea europa L) trees under deficit irrigation. J. Sci. Food Agr. 82:1755-1763.

Vázquez, A., C. Janer del Valle, and M.L. Janer del Valle. 1973. Determinación de polifelnoles totales del aceite de oliva. Grasas y Aceites 24:350-357. 